Miroljub Nikolić ${ }^{1}$

Ministry of Economy, Department for Regional

SCIENTIFIC REVIEW ARTICLE doi:10.5937/ekonomika1504089N

Development and Strategic Analyses of the Economy, Received: September 23, 2015

Belgrade, Serbia

Danijela Despotović ${ }^{2}$

Accepted: November 16, 2015

University of Kragujevac, Faculty of Economics

Dušan Cvetanović ${ }^{3}$

PhD Candidate at the University of Niš, Faculty of Economics

\title{
BARRIERS TO INNOVATION IN SMES IN THE REPUBLIC OF SERBIA
}

\begin{abstract}
Small and medium-sized enterprises (SMEs) face significant constraints in their efforts to be innovative. In addition to general problems in innovation, these business entities in Serbia are faced with additional difficulties which can significantly reduce and limit their innovative strength. In short, these barriers are: personal unreadiness to innovate, underdeveloped awareness of the importance of innovation, inadequate government strategy for supporting innovativeness, limited market, insufficiency of capital, non-innovative organizational culture and insufficient incentives.
\end{abstract}

Key words: SMEs, innovation, barriers to innovation, the Republic of Serbia

JEL classification: 030

\section{ПРЕПРЕКЕ ИНОВИРАЫУ МАЛИХ И СРЕДЫИХ ПРЕДУЗЕТА У РЕПУБЛИЦИ СРБИЈИ}

\begin{abstract}
Апстракт
Мала и средња предузећа се суочавају са значајним ограничењима у својим напорима да буду иновативна. Поред општих проблема код иновирања ови пословни субјекти у Републици Србији се суочавају и са додатним потешкћама које могу значајно да умање и ограниче юихову иновативну снагу. Најкраће, ове препреке су: лична неспремност за иновације, неразвијена свест о значају иновација, неадекватна државна стратегија подршке иновативности, ограничено тржиште, недовољност капитала, неиновативна организациона култура, недовољне стимулације.
\end{abstract}

Кључне речи: мала и средња предузећа, иновачије, препреке иновирању, Република Србија

\footnotetext{
${ }^{1}$ miroljubnk@gmail.com

2 ddespotovic@kg.ac.rs

3 dusan.cvetanovic@ymail.com 


\section{Introduction}

SMEs in the Republic of Serbia operate in the less favourable business environment than SMEs in developed countries, especially in the EU member states. There are many negative factors that affect the daily operations of domestic SMEs including unfavourable general business conditions, unemployment, low purchasing power, undeveloped financial market, limited opportunities for external funding, the grey economy, widespread corruption, inefficient inspection authorities, monopolies in certain industries (e.g. trade), weak legal protection, poor tax regulations and inefficient procedures, inefficient supporting infrastructure, poor law enforcement, etc. To a greater or lesser extent, all these factors affect the possibility, pace and quality of development of SMEs. In addition to the above mentioned factors, there are various constraints which further limit, slow down or hinder innovation activity in SMEs (Mihailović, 2008; Cvetanović \& Nedić, 2013; Kalač et al., 2013). These barriers are able to limit the emergence and rapid development of innovative SMEs, and thus to prevent the achievement of full employment, competitiveness and economic growth.

Besides the risk of failing, which is immanent to every innovative project, there are a number of other barriers that slow down the development of innovation activities in SMEs or make it difficult. The most important barriers that restrict development of innovations in SMEs in the Republic of Serbia are:

- Personal unreadiness to innovate (fear of change, conformity),

- Uninventive social climate and underdeveloped awareness of the importance of innovation,

- Inadequate government strategy for supporting innovation and innovativeness,

- Economic barriers (limited market, insufficiency of capital),

- Business barriers (non-innovative organizational culture, insufficient incentives) (Pokrajac, 2010: 130-131)

\section{Innovativeness factors of SMEs}

Numerous studies point to the important role of internal and external factors for the innovativeness of SMEs. In addition, it turns out that there is no obvious model of influence which applies to all types of innovation. For an enterprise to successfully create a technological innovation, all necessary supply-side and demand-side conditions must be satisfied. Technological knowledge and expertise are essential on the supplyside, and on the demand-side, market opportunities for the realization of innovations are necessary. For example, innovation can enable SMEs to become part of the global supply chain in which SMEs become part (link in the chain) of the overall production process, whether it is a product innovation and/or process innovation. In addition to supply and demand conditions faced by SMEs, some internal factors that are specific to individual enterprises can be crucial to their ability to innovate. The most important internal factors are the availability and quality of human resources, financial strength and absorptive capacity of SMEs. External factors are usually related to the possibility of connection with other companies in the field of innovation, positioning within the supply chain and value chain, etc. 
Black points out that in contemporary conditions the key to successful innovation of SMEs is in the access to knowledge created outside the enterprise (e.g. at research organizations, universities and colleges, research units of large enterprises, institutes, etc.). In their effort to identify what factors determine the speed and quality of innovation within SMEs, Alloca and Kessler (2006) identified and analysed eight major factors:

- Capital resources. Regarding the access to and usage of resources, SMEs have relatively limited opportunities and more difficult access to funding sources; are more dependent on a small number of products or services; cannot achieve economies of scale, etc. On the other hand, they are less bureaucratic structured; are more flexible; are responsive; and have a greater propensity to and need for risk-taking compared to large companies. Due to limited resources (mainly financial), as a rule SMEs have very limited funds for R\&D activities, replacement of the product within the product range, testing of various models of products, etc.

- Marketing and technical resources. As with financial resources, SMEs often have less marketing and technical resources available than large companies. Consequently, there is minor media and marketing presence in the market; it is more difficult for SMEs to establish recognizable trademarks and brands; it is also more difficult for SMEs to present themselves to potential consumers, etc.

- Quality of the management. Management in SMEs has limited and insufficient managerial knowledge (insufficient training in the field of business management, standards of quality, business planning, planning and realization of management activities, connecting with other enterprises, etc.). Personal characteristics of manager (usually the owner) are very important especially in small enterprises, because the success and survival of enterprise mainly depend on abilities, knowledge and initiativenes of the owner (manager).

- Ability to innovate. There is a big difference in terms of the ability to innovate, between SMEs and large enterprises and among SMEs as well. It is noticeable, especially among enterprises from different sectors. What is common to most SMEs are limited capital and human resources, undeveloped business culture (in new enterprises), lack of management experts, lack of experience in developing and connecting into various business networks and associations, etc.

- Innovation process. Main characteristics of SMEs are that their processes usually are less formalized and they often implement informal strategy of planning and communication compared to large enterprises. Consequently, the quality of the innovation process significantly depends on ability and vision of the manager (owner).

- Organizing operations and innovation processes. An important feature of SMEs is that they are more flexible and collectively more motivated, simpler and less bureaucratic structured. This feature enables more rapid decisionmaking compared to large enterprises.

- Strategy and planning. The importance of formal (strategic) planning is less obvious in SMEs compared to large enterprises. Many SMEs avoid defining 
precise goals and clearly defined tasks. Consequently, strategic planning in SMEs is less formalized and unique, and varies among enterprises in terms of importance.

- Forming associations. SMEs are much more motivated and focused on connecting into various associations, networks, business alliances, etc. compared to large enterprises, because they get a chance to overcome some of the limitations that are immanent to small enterprises. In this way they get better access to quality human and all other resources and increase the importance and negotiation power in the market, thereby significantly reducing the advantages of large enterprises. Connecting of SMEs is of great importance because they also disperse financial risks, perform technology transfer in a much easier way, increase production efficiency, competitiveness, etc. (Cvetanovic, et al ., 2014; Alloca \& essler, 2006).

The main conclusion of the research is that because SMEs' innovativeness and complexity are influenced by numerous factors, SMEs must find an efficient way for managing limited financial, human and other resources, in order to be innovative and competitive in the market.

\section{Hampering factors for innovation activities in SMEs in Serbia}

According to the results of the pilot study on innovation activity in enterprises in Serbia ${ }^{1}$ conducted by the Statistical Office of the Republic of Serbia in cooperation with the Institute Mihajlo Pupin for the period 2004-2006, SMEs are faced with a large number of various hampering factors which adversely affect their innovation activities. For most SMEs the most serious hampering factors are lack of financial support from public funds, high costs of innovation funding, unavailability of appropriate funding sources, high costs of direct innovation and operating in markets dominated by established enterprises. Research results show that the most serious restrictions are associated with high costs and inability to finance innovation activities appropriately.

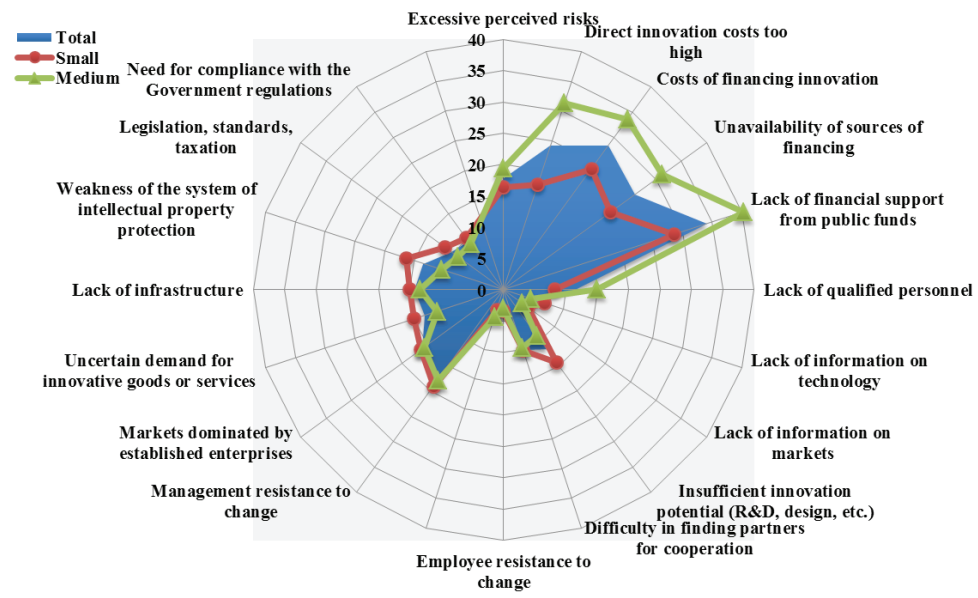

Source: The authors, according to: (Statistical Office of the Republic of Serbia, 2011: 7) 
After a pilot study carried out in 2007, Statistical Office of the Republic of Serbia has conducted two more studies (in 2009 and in 2011) on innovation activity in SMEs. The study conducted in 2011 (referring to the years 2009 and 2010) provided various findings regarding the innovation activity of enterprises, as well as information about factors that hamper the innovation process in SMEs. The survey covered 3,500 small and medium-sized business enterprises, and obtained results were weighted, which enabled their recalculation for the whole population of all SMEs in Serbia. The study separately observed limiting factors for innovation activities in SMEs which are innovators and in SMEs which did not introduce any innovation in observed period.

Separate observation of SMEs that are innovators and SMEs that are not, is based on the works of many relevant authors, such as Arundel (1997), Mohnen \& Rosa (2000), Baldwin \& Lin (2002), Galia \& Legros (2004), Iammarino et al. (2006), Hölzl et al. (2010), etc. All of them show that innovative enterprises consider limiting factors for innovation activities as more important, compared to non-innovative enterprises. Innovative enterprises pay more attention to the barriers and constraints than enterprises that do not innovate. Also, innovative enterprises differ among themselves. More innovative SMEs and SMEs with more intensive R\&D activities pay more attention to constraints and barriers. Therefore the empirical literature views enterprises' responses regarding constraints they encounter when innovate, as an estimate of those enterprises and as a measure of their ability to overcome these problems and constraints.

Galia and Legros, as well as Baldwin and Lin before them, have provided two possible explanations why there are differences in the responses of the enterprises-innovators and enterprises-non-innovators. The first explanation assumes that performing innovation activities increases awareness of the difficulties and constraints that can hamper, slow down and prevent an enterprise from further innovating. The second explanation starts from the formulation of questions in the CIS. In order to answer the questions concerning the barriers to innovation, enterprises have to assess the problems they are faced with and which they need to overcome in carrying out innovation activities.

Hölzl et al. ( 2010) points out that the existing literature on the barriers to innovation is focused on the perception of barriers in innovative enterprises, but does not consider the basic constraints that cause hindering innovation activities in non-innovative enterprises. D'Este, et al., (2008) show that non-innovative enterprises do not have enough interest in performing innovation activities even when barriers to innovation are very low (D'Este et al., 2008). Thus, these enterprises do not tend to be innovative and do not consider constraints the same way the innovative enterprises do. Accordingly, these authors distinguish between revealed barriers and deterring barriers. The former hinder a successful innovation and the latter prevent enterprises from engaging in innovation activities.

Research results on innovation activities in SMEs in Serbia (conducted in 2011) show that the most serious restrictions are cost factors (lack of internal funds, high costs of direct innovation and inability to provide financing of innovation activities from the sources outside the enterprise). Domestic innovative SMEs emphasized also market factors as significant limiting factors for innovation activities (markets dominated by established enterprises and uncertain demand for innovative products). Knowledge factors (such as lack of qualified personnel, lack of information on technologies, lack of information on markets) are the least important for domestic innovative SMEs in terms of limiting innovation activities; the only factor that is slightly more significant for those SMEs is difficulty in finding partners for cooperation. 
Figure 2: Constraints to innovation in SMEs-innovators in Serbia in 2010

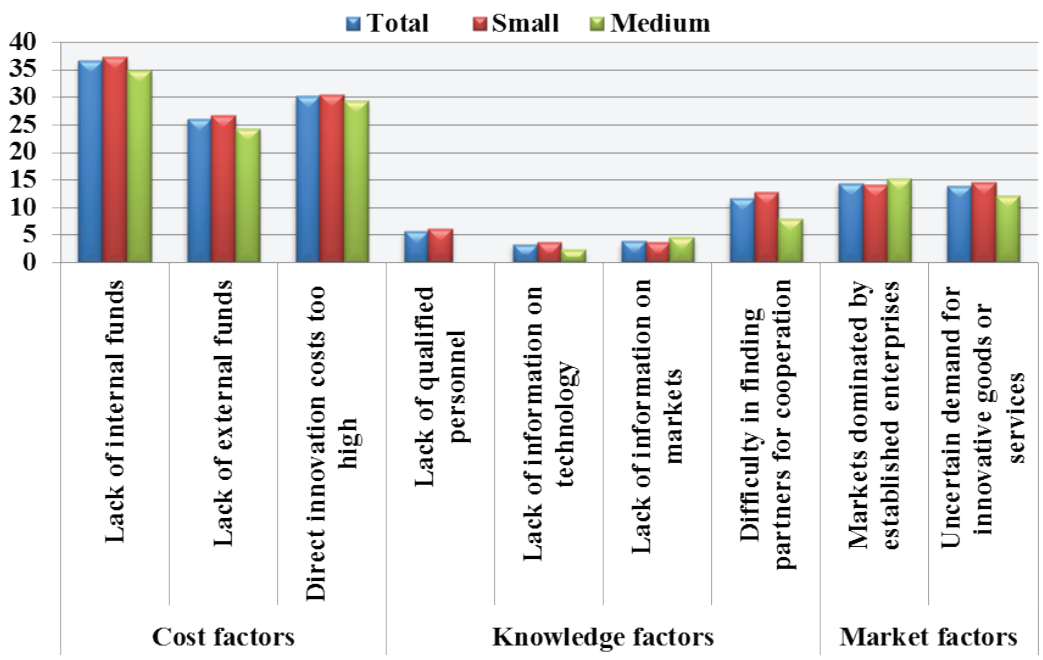

Source: The authors, according to: (Statistical Office of the Republic of Serbia, 2011: 6)

Unlike SMEs-innovators (the highest barriers to innovation are on the cost side), SMEs-non-innovators are faced more with knowledge barriers and market barriers. These enterprises referred to lack of qualified personnel, uncertain demand for innovative products and lack of information on technologies as the most important restrictions. These SMEs presented two main reasons for not innovating: no need to innovate because of lack of demand for innovations; and no need to innovate due to earlier innovations.

Figure 3: Constraints and barriers to innovation in SMEs-non-innovators in Serbia in 2010

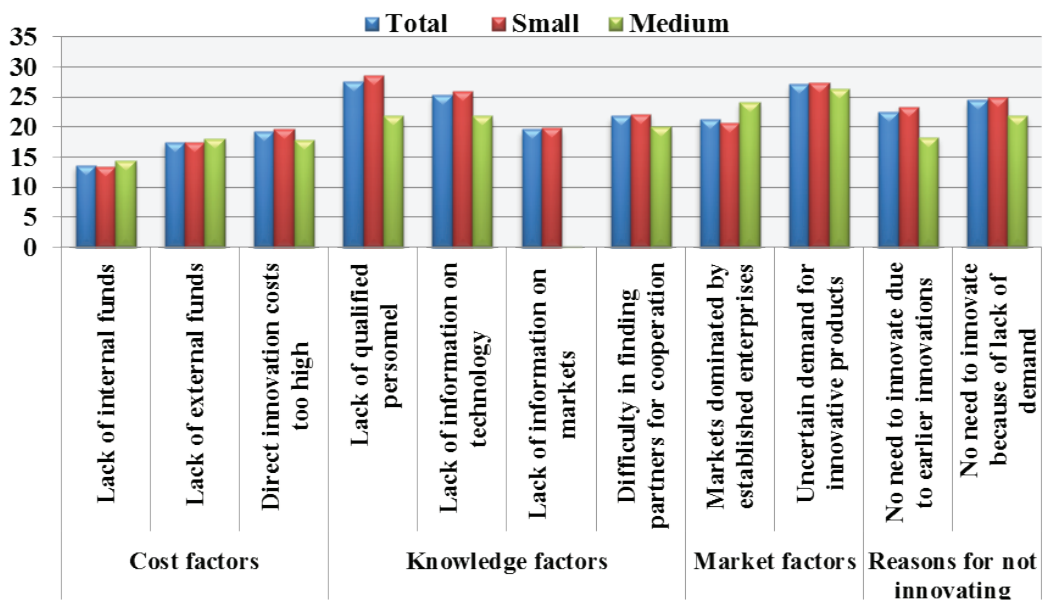

Source: The authors, according to: (Statistical Office of the Republic of Serbia, 2011: 7) 
Only under such circumstances, SMEs are able to express their full developmental potential and contribute to the development of the economy and society as a whole.

\section{Conclusion}

Several studies on barriers to the development of innovation in small and mediumsized enterprises were conducted in the Republic of Serbia. Studying of the barriers was carried out within the broader research aimed at considering the most important factors affecting the operations of SMEs. The main purpose of the above mentioned empirical research was to portray the situation in the economy and use obtained results as a basis for creating development policy. Problems such as macroeconomic instability; poor regulatory, administrative and development policies; unsupportive business environment; systemic corruption; weak rule of law; costly, redundant and inefficient procedures; low levels of education; lack of a skilled workforce; low standard of living, etc. also prevent SMEs in the Republic of Serbia from being successful and more innovative.

\section{References}

Allocca, M. A., \& Kessler, E. H. (2006). Innovation speed in small and medium sized enterprises. Creativity and Innovation Management, 15(3), 279-295.

Arundel, A. (1997). Enterprise strategies and Barriers to innovation, in: Arundel, A., Garrelfs, R. (eds.) Innovation Measurement and Policies, publication 50, EIMS Publication, European Commission, 101-108.

Baldwin, J., \& Lin, Z. (2002). Impediments to advanced technology adoption for Canadian manufacturers. Research policy, 31(1), 1-18.

Cvetanović, S., \& Nedić, V. (2013). Spremnost za umrežavanje u funkciji unapređenja kolaborativnosti malih i srednjih preduzeća. Ekonomika, 59(4), 227-234.

Cvetanovic, S., Nedic, V., \& Eric, M. (2014). Information Technology as A Determinant of SMES Collaboration and Innovativeness. International Journal for Quality Research, 8(4).

D’Este, P., Iammarino, S., Savona, M., \& von Tunzelmann, N. (2008). Barriers to Innovation: Evidence from the UK Community Innovation Survey. SPRU Electronic Working Paper Series. Retrieved from: https://www.sussex.ac.uk/webteam/gateway/ file.php?name $=$ sewp168\&site $=25$. Retrieved date: 01.10 .2015 .

Galia, F., \& Legros, D. (2004). Complementarities between obstacles to innovation: evidence from France. Research policy, 33(8), 1185-1199.

Group of authors (2008) Izveštaj o malim i srednjim preduzećima i preduzetništvu za 2007. godinu, MERR, RZR, NARR, Beograd.

Hölzl, W., Reinstaller, A., Janger, J., Stadler, I., Unterlass, F., Daimer, S., \& Stehnken, T. (2010). Barriers to internationalisation and growth of EU's innovative companies. PRO-INNO Europe: INNO-Grips II report. Retrieved from: http://www.isi. 
fraunhofer.de/isi-wAssets/docs/p/de/publikationen/InnoGrips_Final.pdf . Retrieved date: 01.10 .2015 .

Iammarino, S., Sanna-Randaccio, F., \& Savona, M. (2006). Multinational firms and obstacles to innovation. Evidence from the Italian Community Innovation Survey (CIS3). mimeo, SPRU, University of Sussex.

Kalač, B., Berezljev, L., \& Zahitović, R. (2013). Resursi male i srednje preduzetničke firme i načini njihovog obezbeđivanja. Ekonomika, 59(4), 66-75.

Mihailović, B. (2008). The role of consultancy in development of the small and medium firms in Serbia. Ekonomika,54(1-2),101-110.

Mohnen, P., \& Rosa, J. M. (2002). Barriers to innovation in service industries in Canada (pp. 231-250). Springer US.

Pokrajac, S. (2010). Preduzetništvo: izazovai i putevi „,kreativne destrukcije“ privrede Srbije, Beograd: Mašinski fakultet.

Statistical Office of the Republic of Serbia, (2011). Inovativne aktivnosti malih i srednjih poslovnih subjekata u periodu 2008-2010., Beograd.

Endnotes:

1. Research on innovation activities in Serbia was conducted in order to consider a real attitude of an enterprise business policy toward innovation activities, in terms of awareness of the need for, and the effects of innovation, existing capacities of enterprise as well as the factors that have hampered or slowed down this type of activity. 